\title{
UTJECAJ BEČKE OFTALMOLOŠKE ŠKOLE NA POČETKE SUVREMENE OFTALMOLOGIJE U HRVATSKOJ
}

\author{
THE INFLUENCE OF THE VIENNA SCHOOL OF \\ OPHTHALMOLOGY ON THE BEGINNINGS OF \\ MODERN OPHTHALMOLOGY IN CROATIA
}

\author{
Milan Ivanišević"
}

SAŽETAK

Začetnik Bečke oftalmološke škole bio je prof. dr. Georg Joseph Beer koji je i8ı12. u Beču u Općoj bolnici osnovao Prvu sveučilišnu očnu kliniku u svijetu. Prof. Ferdinand von Arlt vodio ju je 27 godina, od I856. do I883. Budući da je prva očna klinika postala pretijesna, u istoj je bolnici u Beču I883. osnovana Druga sveučilišna očna klinika. Od i885. trideset ju je godina vodio prof. Ernst Fuchs. Mnogi su poznati oftalmolozi još vodili te dvije bečke očne klinike, ali Arlt i Fuchs su bili glavni predstavnici Bečke oftalmološke škole koja se uvijek odlikovala visokim mjerilima u dijagnostici i liječenju očnih bolesti. Mnogi hrvatski oftalmolozi educirali su se kod njih ili kod njihovih učenika te osnivali očne odjele u većim gradovima u Hrvatskoj prenoseći stečeno znanje i iskustvo. Prvi očni odjeli u Hrvatskoj osnovani su na prijelazu iz 19. u 20. stoljeće. Prva sveučilišna očna klinika u Hrvatskoj započela je s radom u Zagrebu i923. Naši oftalmolozi prenijeli su organizaciju klinika kakve su postojale u Beču, $i$ to je bio tadašnji obrazac svih europskih klinika. Tradiciju Bečke oftalmološke škole prenosili su dalje, sljedećim generacijama. U radu su dane i kratke biografije bečkih $i$ hrvatskih oftalmologa i njihovi medusobni odnosi u edukaciji i radu.

Ključne riječi: oftalmologija, povijest, I9. - 20. stoljeće, Bečka oftalmološka škola, Hrvatska

Adresa za dopisivanje: Milan Ivanišević, Katedra za oftalmologiju, Medicinski fakultet, Sveučilište u Splitu, Šoltanska 2, 21000 Split,Hrvatska.E-pošta: milan.ivanisevic@mefst.hr. 


\section{UvoD}

Do početka 19. stoljeća oftalmologija je bila u sklopu kirurgije, interne medicine i anatomije. Konačno se osamostaljuje u kliničkom i akademskom smislu kao grana medicine sredinom i9. stoljeća. U Europi glavni oftalmološki centri bili su u Beču, Londonu, Parizu i Berlinu. ${ }^{1,2,3}$ Budući da je tada Hrvatska bila u sklopu Austro-Ugarske Monarhije, naši prvi oftalmolozi educirali su se krajem Ig. i početkom 20. stoljeća najviše u Beču. Malobrojni hrvatski liječnici učili su oftalmologiju u Grazu, Pragu, Padovi, Parizu i Berlinu. ${ }^{4}$ Bečka oftalmološka škola snažno je utjecala na razvoj hrvatske oftalmologije.

\section{BEČKA OFTALMOLOŠKA ŠKOLA}

Opću bolnicu u Beču (Allgemeines Krankenhaus) osnovao je 1784. car Joseph II., sin Marije Terezije. To je tada bila jedna od najvećih bolnica u svijetu (slika r.). ${ }^{5}$

Prof. dr. Joseph Barth (1746. - i818.), oftalmolog i anatom, osnovao je u njoj Očni odjel I784. i operirao katarakte. ${ }^{6,7}$

Prvu sveučilišnu očnu kliniku u svijetu osnovao je prof. dr. George Joseph Beer (1763. - I82I.), oftalmolog, kirurg i dijelom anatom, u Općoj bolnici u Beču I2. travnja I8ı2. Ta se godina može smatrati rođendanom moderne oftalmologije. Naziv prvog predavanja bio je Praktična i teorijska

1 Cook, Charles (1961), The 150th anniversary of the Moorfields medical school, British Journal of Ophthalmology, 45 (4), 241-50.

2 Galst, Jay M; van Alfen, Peter (2013). Ophthalmologia optica \& Visio in nummis, Piribebuy/New York; Wayenborgh J-P, 23.

3 Kazimirski, Jan (1994). Private Augenkliniken in Berlin und die Augenheilkunde an der Charité von 1800-1881 (Dissertation), Berlin; Medizinischen Fakultät der HumboldtUniversität zu Berlin, 70-7.

4 Vidi više u: Kovačić, Milivoj i sur (1995). Dr. Niko Selak: život i djelo, Koprivnica; Opća bolnica „Dr. T. Bardek“, 53.; Ivanišević, Milan; Bojić, Lovro; Bućan Kajo; Kovačić, Željko (2009), Dr. Erwin Treu-prvi stalni oftalmolog u Splitu, Liječnički vjesnik, 131 (7-8), 233 5.; Vučak, Ivica (2019), Josip Štajduhar: oftalmolog, publicist i urednik glasila slijepih, Liječničke novine, 19 (179), 77-9.; Štambuk, Vjera; Zlatar, Petar; Krstulović, Sanja; Grgić, Roza; Štambuk, Nikica; Soša, Tomislav; Bacelj, Katica; Štampalija, Ante; Smrkinić, Bogomir (1986), Povijest oftalmologije na području Dalmacije, razvoj i sadašnje stanje, Acta Ophthalmologica Iugoslavica, 24 (Supl 3), 121-9.; Dorn, Vjekoslav (1971), Vinko Lušić-Matković - prvi hrvatski školovani oftalmolog, Liječnički vjesnik, 93 (7), 781-6.

5 Grois, Bernhard (1965). Das Allgemeine Krankenhaus in Wien und seine Geschichte, Wien; Maudrich Verlag, 34.

6 Wyklicky, Helmut (1969), The Vienna general hospital, Hippokrates, 40 (11), 439-44.

7 Holubar, Karl (1984), Vienna general hospital-"Allgemeines Krankenhaus"-bicentennial, Israel Journal of Medical Sciences, 20 (6), 553-4. 


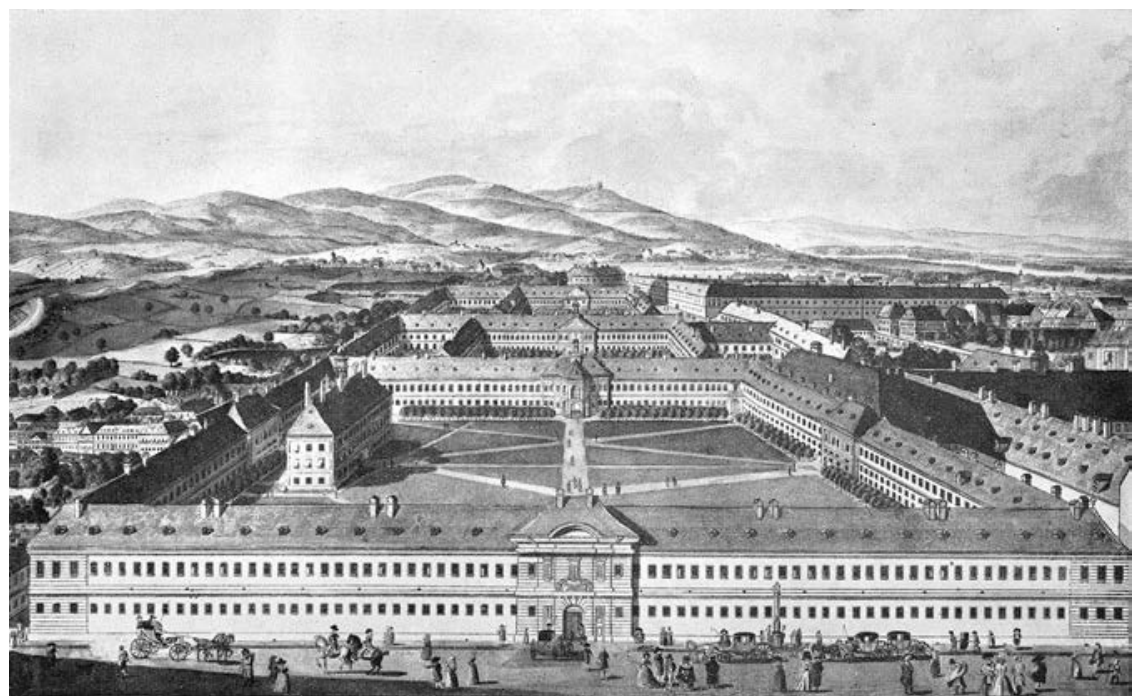

Slika I. Stara bečka Opća bolnica (Allgemeines Krankenhaus), osnovana I784.

oftalmologija. Otad su studenti medicine bili obvezni pohađati predavanja iz oftalmologije. Klinika je bila smještena u petom dvorištu Opće bolnice u Spitalgasse 2 na prvom katu (slika 2.). Sastojala se od predavaonice, koja je služila i kao operacijska dvorana, i dviju soba sa po devet kreveta. Prije

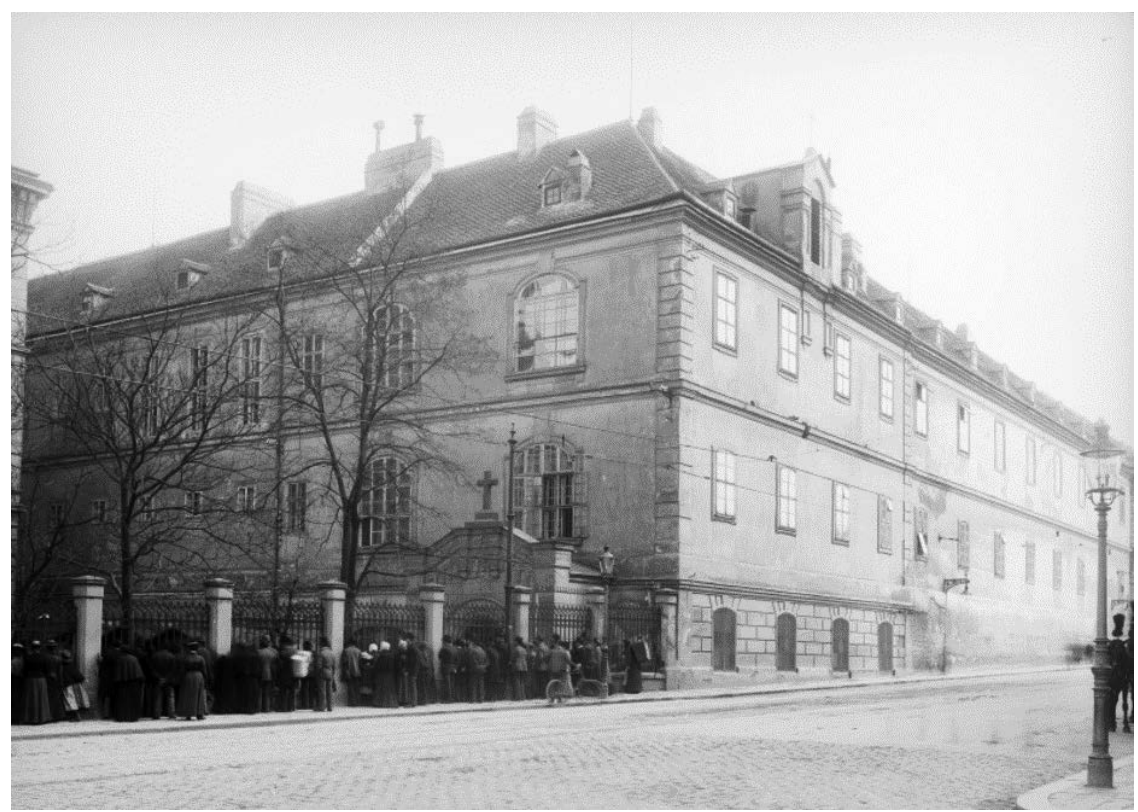

Slika 2. Prva sveučilišna očna klinika u svijetu, osnovana ı8ı2. u Beču. 
toga, I786., prof. Beer osnovao je i prvu privatnu očnu bolnicu u povijesti na Michaelerplatzu u Beču. Od 1793. bilo mu je dopušteno operirati siromašne bolesnike u Općoj bolnici tijekom svibnja i lipnja. Prvu bečku očnu kliniku vodio je do I82r. Bio je iznimno vješt operater. Neki od njegovih najpoznatijih učenika bili su Friedrich von Jaeger, poslije profesor oftalmologije na Vojnomedicinskoj akademiji Josephinum, inače njegov zet i otac oftalmologa Eduarda von Jaegera, Carl Ferdinand von Graefe, „pionir moderne plastične kirurgije“ i otac glasovitog oftalmologa Albrechta von Graefea, Anton von Rosas, njegov nasljednik, Johann Nepomuk Fischer, osnivač moderne oftalmologije u Češkoj, William Mackenzie, osnivač prvoga Očnog odjela u Glasgowu, George Frick, „otac američke oftalmologije“. Bio je začetnik Bečke oftalmološke škole koja je postigla značajnu međunarodnu reputaciju kako za znanstvena istraživanja, tako i za edukaciju. Dotad se oftalmologija smatrala dijelom kirurgije, anatomije i interne medicine. ${ }^{8,9}$

Ferdinand von Arlt (Obergraupen, I7. travnja ı8ı2. - Beč, 7. ožujka I887.), kamen temeljac europske oftalmologije r9. stoljeća, bio je šef Prve bečke očne klinike od ${ }_{1} 86$. do 1883 . (dvadeset i sedam godina) (slika 3.). Na početku svoje karijere bavio se kirurgijom i internom medicinom. Uz to je habilitirao iz otologije i patološke anatomije oka. ${ }^{10}$

Reformirao je ovu svjetski poznatu sveučilišnu očnu kliniku. Obavio je brojna istraživanja u oftalmologiji i posjedovao iznimne operacijske vještine te je znatno utjecao na razvoj oftalmologije. Dok je prije vodio Sveučilišnu očnu kliniku u Pragu, I848. i I85o.

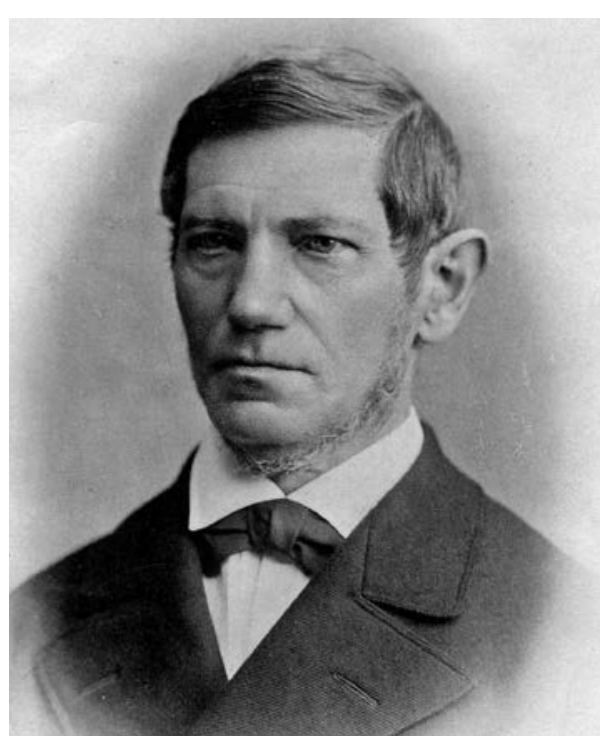

Slika 3. Prof. dr. Ferdinand von Arlt (I812. - I887.), šef Prve bečke očne klinike od I856. do 1883 .

8 Mark, Harry H. (1963), Georg Joseph Beer and ophthalmic training. Archives of Ophthalmology, 69 (1), 131-3.

9 Fanta, Helmut (1989), The founding of the First University Eye Clinic in Vienna, Documenta Ophthalmologica, 71 (2), 195-201.

10 Gerabek, Werner E. (2019), Arlt, Carl Ferdinand, Ritter von Bergschmidt. (2019) https:// kulturportal-west- ost.eu/biographien/arlt-carl-ferdinand-ritter-von-bergschmidt-2 (pristupljeno: 3. rujna 2019.). 
bio je učitelj Albrechta von Graefea (I828. - I870.) kojega je usmjerio prema oftalmologiji. Von Graefe je postao jedan od najpoznatijih oftalmologa svih vremena, modernizirao je oftalmološku struku i definitivno je odvojio od kirurgije. Među poznatijim studentima i asistentima bili su i Ernst Fuchs, Otto Becker, Othmar Purtcher, Friedrich Dimmer, Wilhem Schulek, Otto Bergmeister, Louis de Wecker, Alois Birnbacher, Michael Borysikiewicz i Karl Koller. Arlt je prvi točno opisao trahom i prvi shvatio bit patogeneze kratkovidnosti, a zalagao se i da naočale smiju propisivati jedino okulisti. Njegovi su dobro poznati eponimi Arltov trokut i Arltova operacija pterigija. Naslijedio ga je Karl Stellwag von Carion do I894., a poslije Isidor Schnabel do 1908. ${ }^{11}$

Druga bečka sveučilišna očna klinika bila je smještena u Općoj bolnici, Alserstrasse 4, na prvom katu iznad glavnog ulaza, a osnovana je r. listopada I883. jer je prva postala pretijesna, a i sve je više studenata medicine (slika 4.).

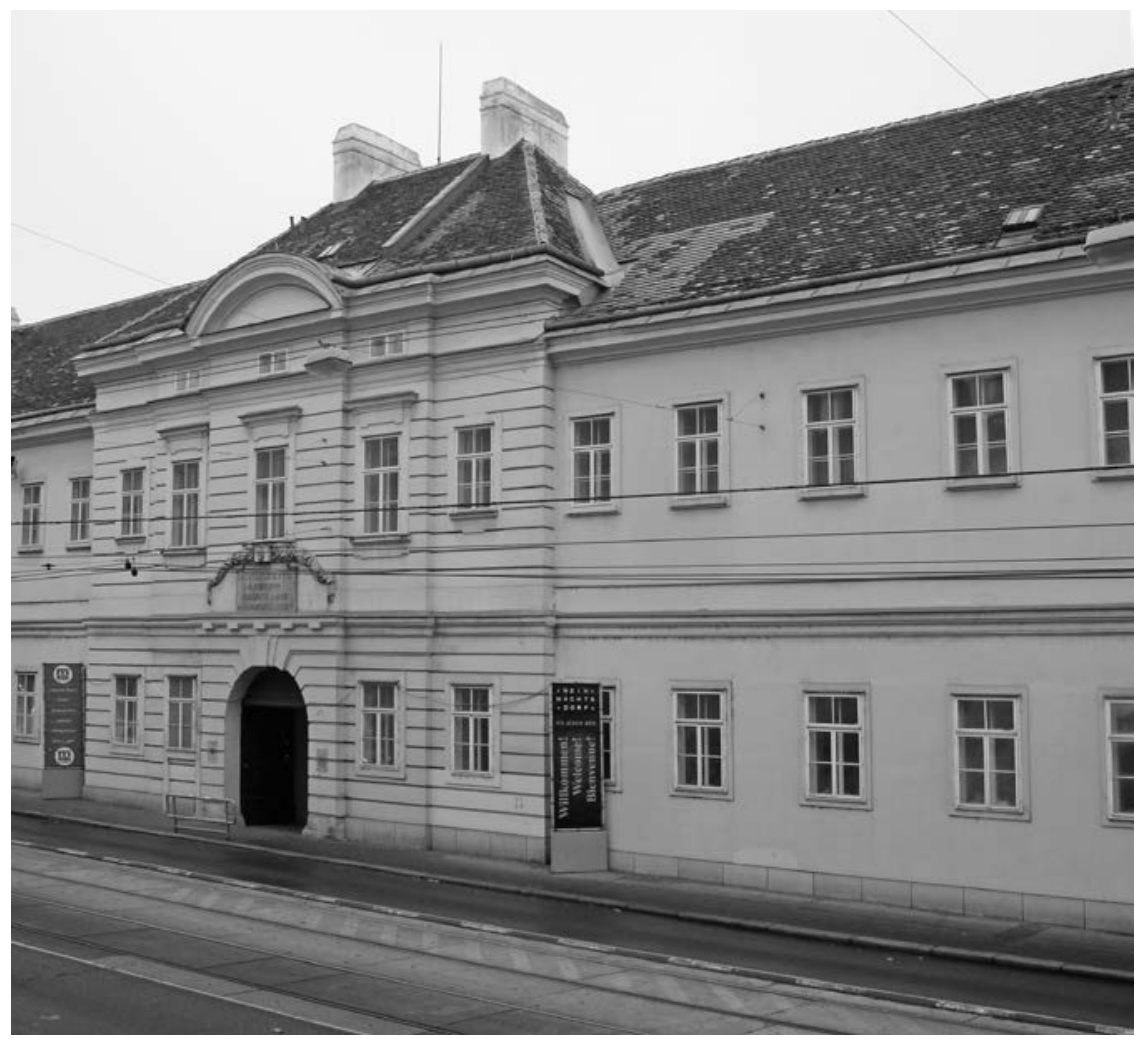

Slika 4. Druga sveučilišna očna klinika u Beču, osnovana I883.

11 Jokl, Alexander (1958), Ferdinand von Arlt and Ernst Fuchs: Two representatives of the Vienna School of Ophthalmology, South African Medical Journal, 32 (11), 301-3. 
Prvi šef bio je eminentni oftalmolog prof. Eduard von Jaeger (I818. - 1884.), sin glasovitog oca Friedricha i unuk G. J. Beera. Vodio ju je samo jednu godinu jer je i884. umro. Bio je vješt operater, prvi se koristio oftalmoskopom u Austriji, objavio je Atlas oftalmoskopije (Ophthalmoskopischer Hand-Atlas) s brojnim ilustracijama koje je sam naslikao te izradio tablice za ispitivanje vida na blizinu. Najprije je radio kao asistent u privatnoj očnoj klinici svoga oca, a od I858. do I883. na Prvoj sveučilišnoj očnoj bečkoj klinici. Njegovi su učenici bili A. von Graefe, I. Schnabel (asistent 1866. - 1870.), L. Mauthner, F. Dimmer. ${ }^{12}$ Drugi šef bio je prof. Ernst Fuchs (Kritzendorf, blizu Beča, I4. lipnja I851. - Beč, 2r. studenoga 1930.) koji je Drugu očnu kliniku vodio trideset godina, najduže od svih, tj. od I885. do 1915. (slika 5.). Nekad su tu kliniku zvali Fuchsova klinika. Bio je asistent F. von Arltu od I876. do i88o. Otkrio je i opisao mnoge očne bolesti i anomalije. Neki od njegovih oftalmoloških eponima su Fuchsova pjega, kornealna distrofija, kolobom žilnice i heterokromni ciklitis. Bio je "otac patološke anatomije oka“. Napisao je i889. udžbenik oftalmologije Lehrbuch der Augenheilkunde koji je pedesetak godina bio „oftalmološka Biblija“. Osnovao je i887. medicinski časopis Wiener Klinische Wochenschrift, koji i danas izlazi. Njegovi učenici su bili W.

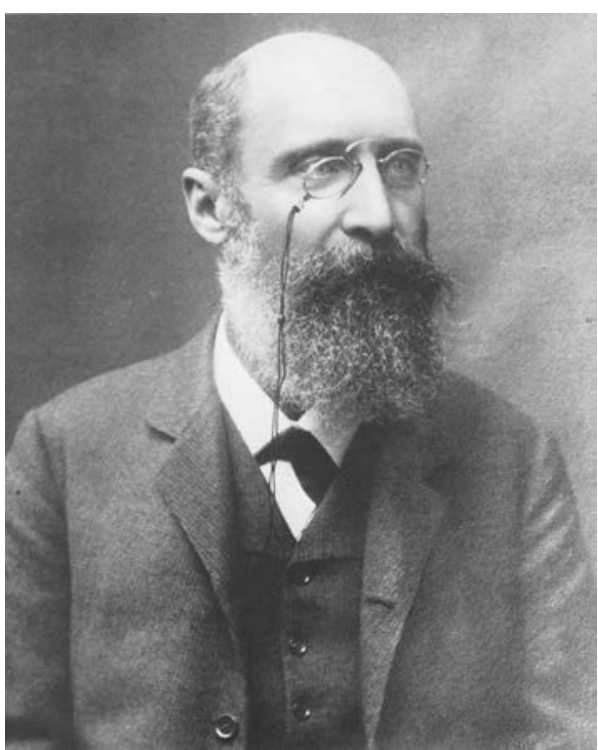

Slika 5. Prof. dr. Ernst Fuchs (I851. - I930.), šef Druge bečke očne klinike od 1885. do 1915.

Czermak, F. Dimmer, M. Salzmann, K. Lindner, J. Meller, A. Botteri, M. Müller i mnogi drugi. U njegovo vrijeme Beč je postao svjetsko središte oftalmologije za kliničku praksu i edukaciju. Njegovo ime bilo je poznato u cijelom svijetu. Smatrali su ga najvećim oftalmologom toga vremena. Za vrijeme Fuchsa Bečka oftalmološka škola doživjela je vrhunac svoje slave i

12 Wyklicky, Helmut (1983). Zur Geschichte der Augenheilkunde in Wien. 100 Jahre II. Universitäts-Augenklinik, Wien; Verlag Christian Brandstätter, 9. 
prepoznatljivosti. Naslijedio ga je F. Dimmer do r926. Obje klinike su se naknadno ujedinile, ali tek I997. godine. . $^{1314}$

Još je jedan Očni odjel u Beču provodio tradiciju Bečke oftalmološke škole u Vojno-medicinsko-kirurškoj akademiji Josephinu. Od ı825. do I848. vodio ga je prof. Friedrich von Jaeger koji je poslije imao svoju privatnu praksu i privatnu bolnicu. Bio je izvrstan operater, ambidekster. Smatrali su ga, kada je bio na vrhuncu svojih aktivnosti, jednim od najboljih očnih kirurga u Europi. Njegovi učenici bili su Julius Sichel (I827. - I829.), osnivač moderne oftalmologije u Francuskoj, Albrecht von Graefe, William Wilde, Eduard von Jaeger. Arlt je tri mjeseca početkom I840. učio izvoditi operacije kod F. von Jaegera. Bio je osobni liječnik princa Metternicha od I8ı6., što govori o njegovu ugledu. Od I855. do I873. Očni je odjel vodio Karl Stellwag von Carion (I823. - I904.), kada je akademija definitivno zatvorena. ${ }^{15}$

Najčešće očne bolesti koje su se tada operirale i liječile u Beču bile su katarakte, ambliopije, reumatski i specifični iritisi, razne očne upale uključujući i trahom.

\section{UlOGA BEČKE OFTALMOLOŠKE ŠKOLE U EDUKACIJI HRVATSKIH OFTALMOLOGA}

S obzirom na državno-pravni položaj Hrvatske tijekom I9. i početkom 20. stoljeća, djelovanje Medicinskog fakulteta, Opće bolnice i Medicinskokirurške akademije Josephinum u Beču izravno je utjecalo na razvoj medicinskih specijalizacija u Hrvatskoj, pa tako i oftalmologije. Tako je i Allgemeines Krankenhaus postala uzor za razvoj novih bolnica u Hrvatskoj i razvoj specijalističkih disciplina, a time i pripadajućih odjela. ${ }^{16}$

Prvu sveučilišnu očnu kliniku u Zagrebu i Hrvatskoj osnovao je 30. siječnja 1923. prof. Albert Botteri (Split, 4. listopada I879. - Zagreb, 20. veljače I955.) u tadašnjoj Marulićevoj ul. I (poslije Kukovićeva ul., danas Ul. A. Kovačića) na prvom i drugom katu zgrade (slika 6.). Kliniku je vodio do I95I., uz prekid tijekom Drugoga svjetskog rata (I943. - I945.) (dvadeset i pet

13 Müller, Andreas; McGhee, Charles N.J. (2003), Professor Ernst Fuchs (1851-1930): a defining career in ophthalmology, Archives of Ophthalmology, 121 (6), 888-91.

14 Tragl, Karl Heinz (2007). Chronik der Wiener Krankenanstalten, Wien/Köln/Weimer; Böhlan Verlag, 207-8.

15 Wyklicky, Helmut (1985). Das Josephinum. Biographie eines Hauses, Wien/München; Christian Brandstätter, 103.

16 Belicza, Biserka (2001), Uloga Bečke medicinske škole u specijalizaciji hrvatskih liječnika od sredine 18. do početka 20. stoljeća, Gazophylacium, 6 (1-2), 97-105. 
godina) (slika 7.). Prije početka specijalizacije surađivao je u Beču s Karlom Landsteinerom (I868.-1943.), poslije dobitnikom Nobelove nagrade za otkriće krvnih grupa. Od 1906. do I908. specijalizirao je oftalmologiju kod prof. Ernsta Fuchsa, šefa na Drugoj sveučilišnoj očnoj klinici u Beču. ${ }^{17}$ Od I9o8. do I9II. radio je kao prvi asistent Očne klinike prof. Stefana Bernheimera (I86r. - I9I8.). Botterijeva klinika bila je suvremeno opremljena po uzoru na srednjoeuropske klinike. Ta povezanost s europskom oftalmologijom očitovala se i r923. kada su kliniku posjetili ugledni gosti Karl Lindner,

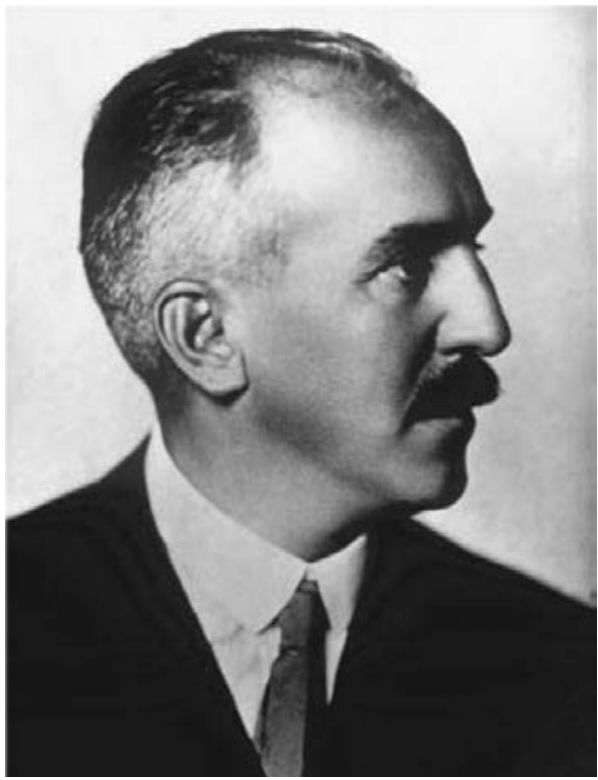

Slika 6. Prof. dr. Albert Botteri (1879. - I955.), osnivač i predstojnik Prve sveučilišne očne klinike u Hrvatskoj od I923. do I95I.

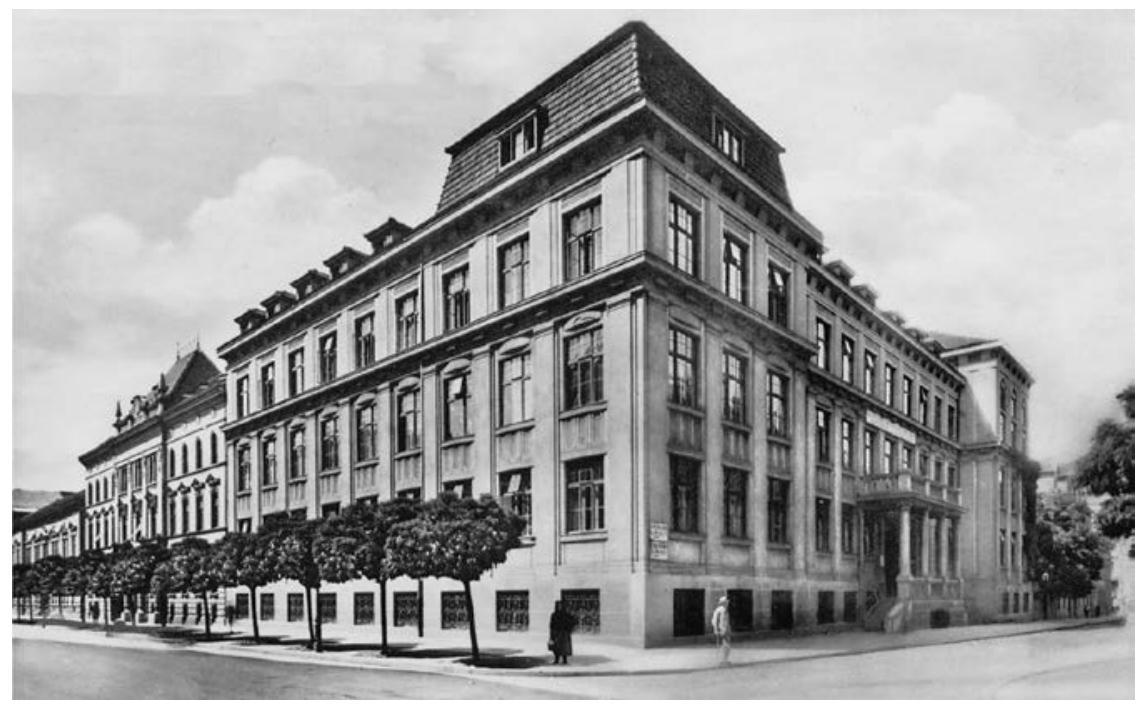

Slika 7. Prva sveučilišna očna klinika u Hrvatskoj, Zagreb, Marulićeva ul. I, osnovana 1923.

17 Pavišić, Zvonimir; Dugački, Vladimir (1980), Značenje znanstvenog, stručnog i nastavnog rada prof. dr. Alberta Botterija za razvoj oftalmologije u Jugoslaviji, Liječnički vjesnik, $102(1), 43-7$. 
docent Druge očne klinike u Beču, i izv. prof. Leonhard Koeppe iz Hallea te održali tečajeve. Botteri je imao prijateljski odnos i s prof. Josefom Mellerom, također Fuchsovim đakom, koji je bio i počasni član našega oftalmološkog društva. Botteri je I9I9. habilitirao za privatnog docenta na Medicinskom fakultetu Karlova sveučilišta u Pragu kod prof. Jana Deyla radnjom o istraživanjima trahoma, uložne blenoreje i proljetnog katara. Tri godine nakon otvaranja, tj. I926., u klinici su bila ukupno 5553 ambulantna bolesnika, 739 kliničkih bolesnika i izvedeno je 1258 operacija. Od ambulantnih bolesnika najviše je bilo onih s običnim konjunktivitisom (Io \%) i trahomskih bolesnika (7\%). Izvedeno je više od četrdeset različitih vrsta operacija. Podjednako je bilo operacija staračke mrene te abrazija i ekspresija trahomskih granula, tj. po $13 \%{ }^{18}$ Botteri je organizirao kliničku nastavu iz oftalmologije, a osobitu je pozornost posvećivao edukaciji znanstvenih i stručnih kadrova i tako omogućio razvoj kliničke i polikliničke oftalmološke škole na području čitave Hrvatske. Odgojio je velik broj vrsnih oftalmologa. Od njih su mnogi postali osnivači i predstojnici odjela i klinika, ne samo u Hrvatskoj već i u čitavoj tadašnjoj Jugoslaviji, pronoseći pozitivne zasade Botterijeve oftalmološke škole. Kliniku za očne bolesti preselio je i946. na Rebro. Od 195ı. do I978. kliniku je vodio njegov asistent akademik prof. dr. Zvonimir Pavišić (1908. - I996.). Danas je to Klinika za očne bolesti Medicinskog fakulteta i KBC-a (Rebro) u Zagrebu. ${ }^{19,20}$

Očni odjel Vinogradske bolnice u Zagrebu vodio je od I904. do i940. doc. dr. Kurt Hühn (Zagreb, 24. studenoga I875. - Rijeka, 9. ožujka I963.) (slika 8.). Dr. Hühn je I905. boravio kod prof. Isidora Schnabela (I842. - I908.) koji je bio šef Prve očne klinike u Beču od I895. do I908. (trinaest godina). Posjećuje i Očnu kliniku u Grazu kod prof. Maximiliana Salzmanna (I862. - I954.) nakon što je Salzmann ı9ı2. postao njezin šef. Poznat po eponimu Salzmannova nodularna distrofija rožnice i po tome što je uveo gonioskopiju. Schnabelova posebna područja istraživanja bila su glaukom i miopija, strabizam i bolesti očnog živca. Poznat je bio kao kirurški vješt oftalmolog i izvrstan predavač. Bio je asistent Eduarda von Jaegera I869./I870. To specijalističko

18 Čavka, Vladimir (1928), Diagnostički, refrakcijoni i ostali podaci o petgodišnjem radu na oftalmološkoj klinici u Zagrebu, Liječnički vjesnik, 50 (2), 57-67.

19 Šikić, Jakov; Cerovski, Branimir; Pokupec, Rajko; Dugački, Vladimir; Dorn, Vjekoslav; Tubaković, Mladen (1993). 70 godina Klinike za očne bolesti Medicinskog fakulteta Sveučilišta u Zagrebu i Kliničkog bolničkog centra u Zagrebu, Zagreb; Klinika za očne bolesti, 5-8.

20 Jukić, Tomislav (2017), Katedra za oftalmologiju i optometriju, u: Pećina, Marko; Klarica, Marijan ur., Medicinski fakultet, Sveučilište u Zagrebu 1917-2017. Zagreb; Sveučilište u Zagrebu-Medicinski fakultet, 633-7. 
usavršavanje K. Hühna odrazilo se u njegovu kasnijem radu na stručnom i znanstvenom polju. Godine igrg. na Karlovom sveučilištu u Pragu habilitirao je kod prof. Jana Deyla za privatnog docenta s temom o trahomu.

Godine rgII. na njegovu odjelu bilo je hospitalizirano 155 bolesnika i izvedeno II59 operacija. Najčešće su operacije bile abrazija spojnice oboljelih od trahoma (48\%) i ekstrakcija mrene $(\mathrm{I} 4,5 \%)$. Veće operacije izvođene su u općoj anesteziji kloroformom, a one manje u lokalnoj anesteziji kokainskim i novokainskim preparatima. Pod njegovim mentorstvom odgojen je čitav niz

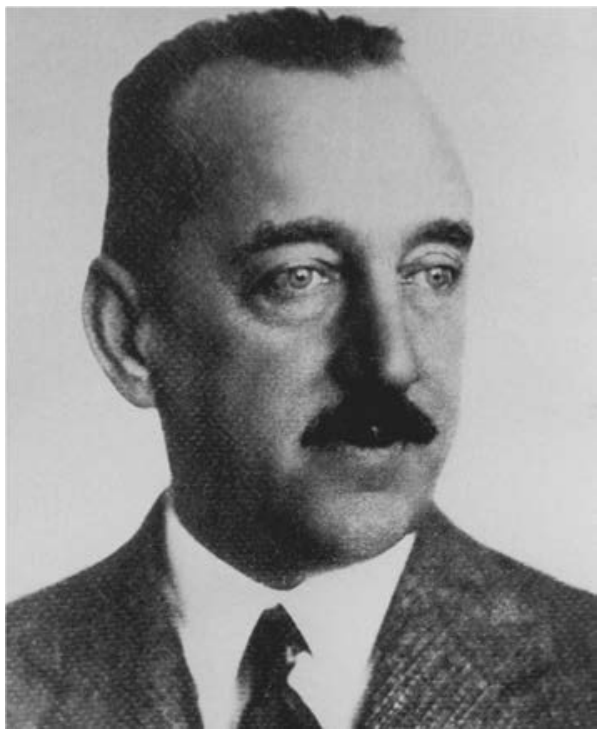

Slika 8. Doc. dr. Kurt Hühn (1875. - 1963.), predstojnik Očnog odjela Bolnice milosrdnih sestara u Zagrebu od 1904. do 1940. vrsnih specijalista. Nakon Hühna odjel je preuzeo njegov učenik prim. dr. Vilko Panac (1895. - 1975.) i vodio ga od 1940. do 1949. ${ }^{21,22}$ Odjel postaje klinika 197I. Danas je to Klinika za očne bolesti KBC-a Sestre milosrdnice i Stomatološkog fakulteta Sveučilišta u Zagrebu.

Prim. dr. Vinko Lušić-Matković (I86I. - I93r.), prvi hrvatski školovani oftalmolog, nije bio izravno đak Bečke oftalmološke škole, ali neki od njegovih učitelja dijelom jesu. Specijalizirao je oftalmologiju od I889. do I892. na očnim klinikama u Grazu (Michael Borysikiewicz, đak F. von Arlta i K. Stellwaga von Cariona), Parizu (Photinos Panas, Louis de Wecker, dak F. von Arlta, E. von Jaegera, A. von Graefea) i Berlinu (Karl Schweigger, đak A. von Graefea). Pri zagrebačkoj Bolnici milosrdne braće, u okviru Eksternog (kirurškog) odjela, osnovao je 1894. Očni trahomski pododjel koji se sljedeće godine pretvara u zaseban odjel (prvi takav u Hrvatskoj), kojemu je bio

21 Dugački, Vladimir (2008), Doc. dr. Kurt Hühn - jedan od začetnika hrvatske oftalmologije, Acta medico-historica Adriatica, 6 (2), 277-84.

22 Mahaček, Franjo (1912), Kratki godišnji izvještaj očnog odjela javne sveopće bolnice milosrdnih sestra u Zagrebu. (Primarius dr. Hühn), Liječnički vjesnik, 8 (34), 377-8. 
voditelj do 1919. Osobito se bavio problemom trahoma, izučavanja biokemije suza i operativnom kazuistikom katarakte. ${ }^{23}$

Prim. dr. Dragutin Certin (1890. - 1970.) bio je voditelj Očnog odjela Bolnice milosrdne braće od r919., a od 1931. do 1949. Bolnice Sv. Duh. Bio je učenik Kurta Hühna. Obavljao je većinu poslova koje je tadašnja oftalmologija znala. Od 1949. do I959. nasljeđuje ga prim. dr. Vilko Panac (I895. - I975.), također učenik Kurta Hühna. Zavod za očne bolesti postaje 20Io. klinika24,25 Danas je to Klinika za očne bolesti Kliničke bolnice Sveti Duh i Medicinskog fakulteta Sveučilišta Josipa Jurja Strossmayera u Osijeku.

Prim. dr. Isidor Garofolo (1863. - 1945.) osnovao je prvi Očni odjel u Bolnici Sveti Duh u Rijeci 1899. i vodio ga do I923. Bio je učenik prof. Isidora Schnabela s Prve bečke očne klinike. ${ }^{26}$ Bavio se i općom medicinom tako da je prvi upotrijebio rendgenski uređaj u riječkoj bolnici 1899. Odjel je I923. preuzeo doc. dr. Albert Filipović (I89I. - I959.) i vodio ga do I959. Specijalizirao je oftalmologiju kod poznatih oftalmologa, prof. Josefa Mellera i prof. Friedricha Dimmera u Beču. Odjel je postao klinika 1963. Danas je to Klinika za oftalmologiju KBC-a Rijeka i Medicinskog fakulteta Sveučilišta u Rijeci. ${ }^{27,28}$

Prim. dr. Miroslav Fritz Müller (1869. - 1922.) osnovao je 1905. Odjel za očne bolesti u Osijeku sa 32 postelje u Huttler-Kohloffer-Monspergerovoj zakladnoj bolnici. Medicinu je završio u Beču i893. Specijalizirao je oftalmologiju na Drugoj očnoj klinici u Beču kod prof. E. Fuchsa. Danas je smješten u kući Kästenbaum (Korsky) koja je primjer mađarske secesije u Chavrakovoj ulici (danas Europska avenija I6). U to doba godišnje se operiralo 80 - Ioo katarakti i liječilo više od 250 trahomskih bolesnika. Trahomski bolesnici liječili su se tuširanjem bolesne spojnice štapićima modre galice (bakarni sulfat), raznim skarifikatorima, Knappovom pincetom. Ti su postupci bili toliko neugodni i bolni da su pacijenti nekad bježali iz bolnice. Naslijedio ga je prim. dr. Radovan Rabar (I892. - I943.) koji je vodio Očni odjel od I923. do I943.

23 Dorn, V. (1971), 781-6.

24 Panian, Zdravko; Zuber, Branko; Jug, Ivan (1986), Historijat Očnog odjela Opće bolnice „Dr Josip Kajfeš“, Acta Ophthalmologica Iugoslavica, 24 (Supl 3), 189-95.

25 Bušić, Mladen (2006). Opća bolnica „Sveti Duh“: 202 godine, Zagreb; Opća bolnica „Sveti Duh", 189-201.

26 Hirschberg, Julius (1992). History of Ophthalmology. The reform of ophthalmology, vol 11. part c (Blodi FC, transl.), Bonn; Wayenborgh J-P, 512.

27 Gligo, Davor; Turčić, Petar (1986), Povijest oftalmologije na području Rijeke i Istre, Acta Ophthalmologica Iugoslavica, 24 (Supl 3), 173-6.

28 Medanić, Ante (1959), Dr. A. Filipović, Liječnički vjesnik, 81 (9-10), 777-8. 
Dr. Rabar specijalizirao je oftalmologiju u Beču kod prof. Josefa Mellera, Fuchsova đaka. ${ }^{29,30,31}$

Odjel, odnosno Zavod za oftalmologiju postaje klinika 2or8. Danas je to Klinika za očne bolesti KBC-a Osijek i Medicinskog fakulteta Sveučilišta Josipa Jurja Strossmayera u n Osijeku.

Prvu stalnu oftalmološku službu u Splitu i u splitskoj bolnici vodio je dr. Erwin Treu (1875. - 1937.) od 1902. Godine 1900. završio je specijalizaciju kod prof. Wilhelm Paul Czermaka (I856. - I906.) na Njemačkoj sveučilišnoj očnoj klinici u Pragu, koju je Czermak vodio od I895. do I9o6. Czermak je bio učenik Ernsta Fuchsa od I887. do I89r. Bio je savjestan kirurg, marljiv učitelj i ljubazan čovjek. ${ }^{32}$ Prema Upisniku bolesnika gradske bolnice u Splitu za 1919. godinu, hospitalizirano je oko pedeset očnih bolesnika, I/3 imala je trahom, a I/6 conjunctivitis eczematosa. Uz druge upale oka i adneksa, ozljede, glaukomske bolesnike, primale su se i senilne katarakte. Prema knjizi operacija gradske bolnice iz 1920., operirao je katarakte (senilna-extractio cataractae c. iridectomia, traumatska, sekundarna-discissio), glaukom (iridektomije), strabizam (tenotomia), ozljede, plastične operacije vjeđa kod ektropija (po Fuchsu, Kuhnt-Szymanovskom), ekstirpacije suzne vrećice, optičke iridektomije i tetovažu kod leukoma rožnice, evisceracije, enukleacije, trahom (kauterizacija, ekspresija po Knappu) i druge. Koristila se uglavnom kokainska anestezija. ${ }^{33}$

Očni odjel u Splitu osnovao je I. rujna 1921. dr. Juraj Ćurin (I887. - I947.) koji je završio specijalizaciju iz oftalmologije r92r. kod K. Hühna, a ovaj je bio đak Isidora Schnabela s Prve očne klinike u Beču. Dr. Ćurin osniva 1923. u Splitu ambulantu za trahom u kojoj je 1925. i i926. bilo pregledano 370 trahomskih bolesnika i izvedeno trideset operacija. Godine ig26. u splitskoj gradskoj bolnici liječena su 183 bolesnika s bolestima oka i njegovih adneksa. Godine 1928. dr. Ćurin obavio je Ios operacija: katarakte, kronični i akutni glaukom, ozljede oka, strabizam, epiteliomi oka i vjeđa, ekstrirpacije suznih

29 Balog, Zlatko; Kratofil, Boris; Barać, Josip (1998). Osijek i Očni odjel u slici i riječi. Knjiga sažetaka. 5. godišnji sastanak Hrvatskog oftalmološkog društva s međunarodnim sudjelovanjem. Osijek, 3.

30 Vranješ, Željko; Glavina, Krešimir (2009), Od Zakladne bolnice do Kliničkog bolničkog centra u Osijeku, Medicinski vjesnik, 41 (3-4), 27-40.

31 Utvić, Vladimir (1974). Povijest bolničkih ustanova u Osijeku od 1874.-1974. 2. dio, Osijek; Opća bolnica Osijek, 117-30.

32 Hruby, Karl (1985), Aufstieg und Untergang der Deutschen Universitäts-Augenklinik in Prag, Klinische Monatsblätter für Augenheilkunde, 187 (4), 307-13.

33 Ivanišević, M. (2009), 233-5. 
vrećica kod dakriocistitisa, pterigiji, plastične operacije vjeđa, enukleacije oka, egzenteracije orbite, punkcije prednje sobice, optičke iridektomije i dr. ${ }^{34}$

Dugogodišnji šef Očnog odjela u Splitu prof. Dinko Šakić (1904. - 1973.) bio je asistent Alberta Botterija od 1931. do 1934., a ovaj Ernsta Fuchsa. Vodio je Očni odjel u Splitu trideset i sedam godina, od 1936. do 1973. ${ }^{35}$ Akademik prof. dr. Zvonimir Pavišić za njega je 1974. rekao: „...bio je brižan savjetnik u razvoju oftalmološke misli. Na temelju svog bogatog kliničkog iskustva i znanja medicinskog erudite, komponirao je simfoniju svojih oftalmoloških radova, naročito na području operativne terapije, glaukoma, katarakte, upala rožnice, uveje i orbite... Kao najeminentniji oftalmolog Dalmacije odgojio je cijeli niz oftalmologa stručnjaka..."36

Godine 1986. odjel postaje klinika. Danas je to Klinika za očne bolesti Kliničkoga bolničkog centra Split i Medicinskog fakulteta Sveučilišta u Splitu. ${ }^{37}$

\section{UTJECAJ BEČKE OFTALMOLOŠKE ŠKOLE NA RAZVOJ OFTALMOLOGIJE U HRVATSKoJ}

U početku je na razvoj hrvatske oftalmološke sužbe u velikim gradovima - Zagrebu, Rijeci, Splitu i Osijeku gotovo isključivo utjecala Bečka oftalmološka škola. Nekad je bio izravan utjecaj Prve, a nekad Druge bečke očne klinike, a nekad i jedne i druge. Način rada i operacije koje su se izvodile u našim oftalmološkim centrima bile su identične kao u i bečkim očnim klinikama.

Klinika za očne bolesti Medicinskog fakulteta u Zagrebu bila je pretežno pod utjecajem Druge bečke očne klinike. Njezin osnivač prof. A. Botteri specijalizirao je oftalmologiju kod prof. Ernsta Fuchsa. Klinika za očne bolesti Sestara milosrdnica u Zagrebu bila je pod utjecajem Prve bečke očne klinike. Njihov dugogodišnji šef Hühn boravio je kod prof. Isidora Schnabela, voditelja Prve bečke očne klinike. Klinika za očne bolesti na Svetom Duhu na

34 Ivanišević, Milan; Bojić, Lovro; Bućan, Kajo; Ivanišević, Petar; Kovačić, Željko (2010), Dr. Juraj Ćurin: osnivač očnog odjela u Splitu, Acta Medica Croatica, 64 (1), 59-63.

35 Juretić, Miro; Dugački, Vladimir; Krstulović, Sanja; Karaman, Ksenija (1999). Prof. dr. Dinko Šakić, prvi sveučilišni nastavnik medicine u Dalmaciji, u: Kraljević, Ljubomir ur., Zaslužni splitski liječnici u prošlosti od 1946. do 1975. godine, Split; Hrvatski liječnički zbor-podružnica, 75-83.

36 Pavišić, Zvonimir (1974), In memoriam Prof. Dr. Dinko Šakić, Liječnički vjesnik, 96 (3), 192.

37 Ivanišević, Milan (2017), Katedra za oftalmologiju, u: Đogaš, Zoran; Ivanišević, Milan ur., Medicinski fakultet: monografija povodom dvadesete obljetnice 1997.-2017, Split; Medicinski fakultet Sveučilišta u Splitu, 401-12. 
čelu s prim. dr. Dragutinom Certinom i poslije prim. dr. Vilkom Pancom pod utjecajem doc. dr. Kurta Hühna, učenika Prve bečke očne klinike. Klinika za oftalmologiju u Rijeci u svojim počecima bila je pod utjecajem Prve bečke očne klinike jer je osnivač i prvi šef prim. dr. Isidor Garofolo bio učenik prof. Isidora Schnabela. Klinika za očne bolesti u Osijeku u svojim počecima vezana je za Drugu očnu kliniku u Beču. Njezin je osnivač prim. dr. Miroslav Müller bio učenik prof. Ernsta Fuchsa. Očna klinika u Splitu većim je dijelom vezana uz Drugu očnu kliniku u Beču, a manjim za Prvu bečku očnu kliniku. Prvi oftalmolog u splitskoj bolnici dr. Erwin Treu specijalizirao je kod prof. Wilhelma Czermaka, koji je bio asistent prof. Ernsta Fuchsa. Osnivač Očnog odjela u Splitu dr. Juraj Ćurin bio je na specijalizaciji kod doc. Kurta Hühna, asistenta Isidora Schnabela, a dugogodišnji šef Očnog odjela u Splitu prof. Dinko Šakić specijalizirao je kod prof. Alberta Botterija, asistenta prof. Ernsta Fuchsa.

Bilo je i manjih utjecaja Očne klinike u Innsbrucku na prof. Botterija i Očne klinike u Grazu na doc. Hühna. ${ }^{38,39}$ Prim. dr. Vinko Lušić-Matković bio je pod utjecajem očnih klinika u Grazu, Parizu i Berlinu tako da nije izravno bio đak Bečke oftalmološke škole. ${ }^{40}$

\section{NAJČEŠĆE OfTALMOLOŠKE BOLESTI POČETKOM 2O. STOLJEĆA}

Naši prvi školovani oftalmolozi imali su vrlo kvalitetnu oftalmološku obuku i svojim su se znanjem koristili u djelotvornom liječenju očnih bolesnika i prenosili ga na mlađe generacije.

U prvih tridesetak godina 20. stoljeća trahom je bio jedan od vodećih problema nacionalne patologije. Okulist dr. Vladimir Jelovšek (I879. - I934.) objavljuje i9ıI. zdravstveno-prosvjetnu knjižicu o očnim bolestima i manama vida, s osobitim obzirom na trahom. To je bila prva hrvatska stručna medicinska oftalmološka knjiga. Trahomom su osobito bila zahvaćena područja u Međimurju, Podravini i Posavini. ${ }^{41} \mathrm{Za}$ liječenje trahoma koristio se modri kamen kojim se premazivala spojnica te se primjenjivala kauterizacija, abrazija i ekspresija trahomskih granula. Od četrdesetih godina 20. stoljeća trahom se

\footnotetext{
Pavišić, Z. (1980), 43-7.

Dugački, V. (2008), 277-84.

Dorn, V. (1971), 781-6.

Jelovšek, Vladimir (1911). Naše očne bolesti (Trahom), Zagreb; Tiskara „Pučke Prosvjete“, 71-93.
} 
liječio sulfonamidima, a od pedesetih godina krenula je djelotvorna terapija antibioticima - tetraciklinima. ${ }^{42}$

Najčešća operacija na samom oku bila je ekstrakcija katarakte kako na početku 20. stoljeća, tako i danas. Međutim, danas je broj operacija katarakte oko deset puta veći zbog dužega životnog vijeka ljudi, dostupnosti zdravstvene skrbi, modernih tehnika operacija katarakte, načina života i indikacija za operaciju, tj. danas se ne čeka da bolesnik potpuno oslijepi od katarakte. ${ }^{43,44,45}$

\section{ZAKLJUČAK}

Hrvatskoj je oftalmologiji još prije stotinu i trideset godina poticaj dala Bečka oftalmološka škola. Glavni njezini predstavnici u Hrvatskoj bili su prof. dr. Albert Botteri i doc. dr. Kurt Hühn. Pod njihovim mentorstvom odgojen je čitav niz vrsnih specijalista koji su dalje prenosili oftalmološka znanja i vještine. Hrvatski oftalmolozi i danas, na početku 2r. stoljeća, prate i primjenjuju sve najnovije oftalmološke dijagnostičke i terapijske postupke suvremenog svijeta. Od 1992. imaju svoje Hrvatsko oftalmološko društvo i svoj oftalmološki časopis Ophthalmologia Croatica, održavaju redovite stručne sastanke, tj. svake se godine organizira oftalmološki kongres s međunarodnim sudjelovanjem, zatim simpozij Suvremeno u oftalmologiji krajem svake godine te sastanke Sekcija Hrvatskoga oftalmološkog društva. U Hrvatskoj danas ima oko 450 oftalmologa, šest očnih klinika (Zagreb, Split, Rijeka, Osijek) i dobro raspoređenu mrežu očnih odjela i službi unutar države. Tome treba pridodati i privatnu bolnicu za oftalmologiju u Zagrebu te brojne očne poliklinike i ambulante diljem Hrvatske.

42 Feibel, Robert M. (2011), Fred Loe, MD, and the history of trachoma, Archives of Ophthalmology, 129 (4), 503-8.

43 Čavka, V. (1928), 57-67.

44 Domac, Julije (1915), Godišnji izvještaj (1914.) iz očnog odjela bolnice milosrdnih sestara u Zagrebu, Liječnički vjesnik, 37 (2), 39-41.

45 Cerovski, Branimir (2013). 90 godina Klinike za očne bolesti Kliničkog bolničkog centra Zagreb i Medicinskog fakulteta Sveučilišta u Zagrebu 1923.-2013, Zagreb; Stega tisak d.o.o., 25-7. 


\section{LITERATURA}

1. Balog, Zlatko; Kratofil, Boris; Barać, Josip (1998). Osijek i Očni odjel u slici i riječi. Knjiga sažetaka. 5. godišnji sastanak Hrvatskog oftalmološkog društva s međunarodnim sudjelovanjem. Osijek, 3.

2. Belicza, Biserka (2001), Uloga Bečke medicinske škole u specijalizaciji hrvatskih liječnika od sredine 18. do početka 20. stoljeća, Gazophylacium, 6 (1-2), 97-105.

3. Bušić, Mladen (2006). Opća bolnica „Sveti Duh“: 202 godine, Zagreb; Opća bolnica „Sveti Duh“, 189-201.

4. Cerovski, Branimir (2013). 90 godina Klinike za očne bolesti Kliničkog bolničkog centra Zagreb i Medicinskog fakulteta Sveučilišta u Zagrebu 1923.-2013, Zagreb; Stega tisak d.o.o., 25-7.

5. Cook, Charles (1961), The 150th anniversary of the Moorfields medical school, British Journal of Ophthalmology, 45 (4), 241-50.

6. Čavka, Vladimir (1928), Diagnostički, refrakcijoni i ostali podaci o petgodišnjem radu na oftalmološkoj klinici u Zagrebu, Liječnički vjesnik, 50 (2), 57-67.

7. Domac, Julije (1915), Godišnji izvještaj (1914.) iz očnog odjela bolnice milosrdnih sestara u Zagrebu, Liječnički vjesnik, 37 (2), 39-41.

8. Dorn, Vjekoslav (1971), Vinko Lušić-Matković - prvi hrvatski školovani oftalmolog, Liječnički vjesnik, 93 (7), 781-6.

9. Dugački, Vladimir (2008), Doc. dr. Kurt Hühn - jedan od začetnika hrvatske oftalmologije, Acta medico-historica Adriatica, 6 (2), 277-84.

10. Fanta, Helmut (1989), The founding of the First University Eye Clinic in Vienna, Documenta Ophthalmologica, 71 (2), 195-201.

11. Feibel, Robert M. (2011), Fred Loe, MD, and the history of trachoma, Archives of Ophthalmology, 129 (4), 503-8.

12. Galst, Jay M; van Alfen, Peter (2013). Ophthalmologia optica \& Visio in nummis, Piribebuy/New York; Wayenborgh J-P, 23.

13. Gerabek, Werner E. (2019), Arlt, Carl Ferdinand, Ritter von Bergschmidt. (2019) https://kulturportal-west-ost.eu/biographien/arlt-carl-ferdinand-ritter-von-bergschmidt-2 (pristupljeno: 3. rujna 2019.).

14. Gligo, Davor; Turčić, Petar (1986), Povijest oftalmologije na području Rijeke i Istre, Acta Ophthalmologica Iugoslavica, 24 (Supl 3), 173-6.

15. Grois, Bernhard (1965). Das Allgemeine Krankenhaus in Wien und seine Geschichte, Wien; Maudrich Verlag, 34.

16. Hirschberg, Julius (1992). History of Ophthalmology. The reform of ophthalmology, vol 11. part c (Blodi FC, transl.), Bonn; Wayenborgh J-P, 512.

17. Holubar, Karl (1984), Vienna general hospital-"Allgemeines Krankenhaus"bicentennial, Israel Journal of Medical Sciences, 20 (6), 553-4.

18. Hruby, Karl (1985), Aufstieg und Untergang der Deutschen UniversitätsAugenklinik in Prag, Klinische Monatsblätter für Augenheilkunde, 187 (4), 307-13. 
19. Ivanišević, Milan (2017). Katedra za oftalmologiju, u: Đogaš, Zoran; Ivanišević, Milan ur., Medicinski fakultet: monografija povodom dvadesete obljetnice 1997.-2017, Split; Medicinski fakultet Sveučilišta u Splitu, 401-12.

20. Ivanišević, Milan; Bojić, Lovro; Bućan Kajo; Kovačić, Željko (2009), Dr. Erwin Treu-prvi stalni oftalmolog u Splitu, Liječnički vjesnik, 131 (7-8), 233-5.

21. Ivanišević, Milan; Bojić, Lovro; Bućan, Kajo; Ivanišević, Petar; Kovačić, Željko (2010), Dr. Juraj Ćurin: osnivač očnog odjela u Splitu, Acta Medica Croatica, 64 (1), 59-63.

22. Jelovšek, Vladimir (1911). Naše očne bolesti (Trahom), Zagreb; Tiskara „Pučke Prosvjete“, 71-93.

23. Jokl, Alexander (1958), Ferdinand von Arlt and Ernst Fuchs: Two representatives of the Vienna School of Ophthalmology, South African Medical Journal, 32 (11), 301-3.

24. Jukić, Tomislav (2017), Katedra za oftalmologiju i optometriju, u: Pećina, Marko; Klarica, Marijan ur., Medicinski fakultet, Sveučilište u Zagrebu 1917-2017. Zagreb; Sveučilište u Zagrebu-Medicinski fakultet, 633-7.

25. Juretić, Miro; Dugački, Vladimir; Krstulović, Sanja; Karaman, Ksenija (1999). Prof. dr. Dinko Šakić, prvi sveučilišni nastavnik medicine u Dalmaciji, u: Kraljević, Ljubomir ur., Zaslužni splitski liječnici u prošlosti od 1946. do 1975. godine, Split; Hrvatski liječnički zbor-podružnica, 75-83.

26. Kazimirski,Jan (1994). Private Augenkliniken in Berlin und die Augenheilkunde an der Charité von 1800-1881 (Dissertation), Berlin; Medizinischen Fakultät der Humboldt-Universität zu Berlin, 70-7.

27. Kovačić, Milivoj i sur (1995). Dr. Niko Selak: život i djelo, Koprivnica; Opća bolnica „Dr. T. Bardek“, 53.

28. Mahaček, Franjo (1912), Kratki godišnji izvještaj očnog odjela javne sveopće bolnice milosrdnih sestra u Zagrebu. (Primarius dr. Hühn), Liječnički vjesnik, 8 (34), 377-8.

29. Mark, Harry H. (1963), Georg Joseph Beer and ophthalmic training. Archives of Ophthalmology, 69 (1), 131-3.

30. Medanić, Ante (1959), Dr. A. Filipović, Liječnički vjesnik, 81 (9-10), 777-8.

31. Müller, Andreas; McGhee, Charles N.J. (2003), Professor Ernst Fuchs (18511930): a defining career in ophthalmology, Archives of Ophthalmology, 121 (6), 888-91.

32. Panian, Zdravko; Zuber, Branko; Jug, Ivan (1986), Historijat Očnog odjela Opće bolnice „Dr Josip Kajfeš“, Acta Ophthalmologica Iugoslavica, 24 (Supl 3), 189-95.

33. Pavišić, Zvonimir (1974), In memoriam Prof. Dr. Dinko Šakić, Liječnički vjesnik, $96(3), 192$.

34. Pavišić, Zvonimir; Dugački, Vladimir (1980), Značenje znanstvenog, stručnog i nastavnog rada prof. dr. Alberta Botterija za razvoj oftalmologije u Jugoslaviji, Liječnički vjesnik, 102 (1), 43-7. 
35. Šikić, Jakov; Cerovski, Branimir; Pokupec, Rajko; Dugački, Vladimir; Dorn, Vjekoslav; Tubaković, Mladen (1993). 70 godina Klinike za očne bolesti Medicinskog fakulteta Sveučilišta u Zagrebu i Kliničkog bolničkog centra u Zagrebu, Zagreb; Klinika za očne bolesti, 5-8.

36. Štambuk, Vjera; Zlatar, Petar; Krstulović, Sanja; Grgić, Roza; Štambuk, Nikica; Soša, Tomislav; Bacelj, Katica; Štampalija, Ante; Smrkinić, Bogomir (1986), Povijest oftalmologije na području Dalmacije, razvoj i sadašnje stanje, Acta Ophthalmologica Iugoslavica, 24 (Supl 3), 121-9.

37. Tragl, Karl Heinz (2007). Chronik der Wiener Krankenanstalten, Wien/Köln/ Weimer; Böhlan Verlag, 207-8.

38. Utvić, Vladimir (1974). Povijest bolničkih ustanova u Osijeku od 1874.-1974. 2. dio, Osijek; Opća bolnica Osijek, 117-30.

39. Vranješ, Željko; Glavina, Krešimir (2009), Od Zakladne bolnice do Kliničkog bolničkog centra u Osijeku, Medicinski vjesnik, 41 (3-4), 27-40.

40. Vučak, Ivica (2019), Josip Štajduhar: oftalmolog, publicist i urednik glasila slijepih, Liječničke novine, 19 (179), 77-9.

41. Wyklicky, Helmut (1969), The Vienna general hospital, Hippokrates, 40 (11), 439-44.

42. Wyklicky, Helmut (1983). Zur Geschichte der Augenheilkunde in Wien. 100 Jahre II. Universitäts-Augenklinik, Wien; Verlag Christian Brandstätter, 9.

43. Wyklicky, Helmut (1985). Das Josephinum. Biographie eines Hauses, Wien/ München; Christian Brandstätter, 103.

\section{SUMMARY}

The founder of the Vienna School of Ophthalmology was Prof. Dr. Georg Joseph Beer, who founded the First University Eye Clinic in the Vienna General Hospital in I812. Prof. Ferdinand von Arlt led it for 27 years from 1856 to I883. As the First Eye Clinic became too small, the Second University Eye Clinic was founded in 1883 at the same hospital in Vienna. Since 1885 it had been led for 30 years by Prof. Ernst Fuchs. Many well-known ophthalmologists were leading those Viennese eye clinics. However, Arlt and Fuchs were the main representatives of the Vienna School of Ophthalmology, which was always characterised by the high standards in the diagnosis and therapy of eye diseases. Many Croatian ophthalmologists were educated by them or their students, and later they established eye departments in the major cities in Croatia and transmitted acquired knowledge and experience. The first eye departments in Croatia were formed at the turn of the Igth and 2oth century. The First University Eye Clinic in Croatia started to work in Zagreb in 1923. Our ophthalmologists transmitted the organisation of the clinics as they existed in Vienna, and that was the matrix form of all European clinics at that time. Therefore, the tradition of the Vienna School of Ophthalmology was passed on to the next generations. The paper also gives short biographies of Viennese and Croatian ophthalmologists and their mutual relations in education and work.

Keywords: ophthalmology, history, Igth-2oth century, Vienna School of Ophthalmology, Croatia 